\title{
MINAT SISWA DALAM MELANJUTKAN STUDI PERGURUAN TINGGI DI SMK NEGERI 1 TALANG UBI
}

\author{
Nabila Putri Gusmi \\ SMK NEGERI 1 TALANG UBI \\ Email: nabilaputri@gmail.com
}

\begin{abstract}
ABSTRAK
Tujuan penelitian ini untuk mengetahui persentase minat siswa dalam melanjutkan studi perguruan tinggi dan bagaimana implikasi bimbingan dan konseling terhadap minat siswa dalam melanjutkan studi perguruan tinggi. Metode Penelitian ini merupakan penelitian Kuantitatif deskriptif, dengan menggunakan pendekatan kuantitatif. Subjek penelitian ini berjumlah 30 siswa kelas X SMK Negeri 1 Talang Ubi yang diambil dengan menggunakan teknik purposive sampling. Instrumen yang digunakan berupa angket minat siswa melanjutkan studi perguruan tinggi. Analisis datanya menggunakan rumus Persentase. Hasil penelitian menunjukan bahwa minat siswa dalam melanjutkan studi perguruan tinggi di SMK Negeri 1 Talang Ubi yang terdiri dari 30 siswa sebagian besar mereka berada pada kategori Tinggi (T) dengan jumlah frekuensi 15 siswa atau dapat dipersentasekan dengan nilai 50\%. Selanjutnya disusul pada kategori sangat tinggi (ST) dengan jumlah frekuensi 10 siswa yang dapat dipersentasekan dengan nilai 33,3\%. Kemudian minat siswa berada pada kategori sedang $(S)$ dengan jumlah frekuensi 5 siswa yang dapat dipersentasekan dengan nilai 16,7\% dan tidak ada siswa yang berada pada kotegori rendah dan sangat rendah. Berdasarkan data diatas maka rata-rata minat siswa dalam melanjutkan studi perguruan tinggi berada pada kategori tinggi. Dalam hal ini guru bimbingan dan konseling sangat berperan penting dalam mempertahankan minat siswa dengan memberikan arahan kepada siswa untuk mengikuti sosialisasi mengenai beasiswa perguruan tinggi dan mengikuti seminar perguruan tinggi agar mereka selalu termotivasi dalam mempertahankan minat dalam melanjutkan studi perguruan tinggi.
\end{abstract}

Kata kunci:Minat, Perguruan Tinggi, Bimbingan Konseling

\section{STUDENT INTEREST IN CONTURING EDUCATION STUDY AT VOCATIONAL SHOOL 1 TALANG UBI}

\begin{abstract}
The purpose of this study was to determine the percentage of student interest in continuing college studies and how the implications of guidance and counseling on student interest in continuing college studies.This research method is a descriptive quantitative research, using a quantitative approach. The subjects of this study is 30 students of class X SMK Negeri 1 Talang Ubi who were taken using purposive sampling technique. The instrument used was a questionnaire on
\end{abstract}


the interest of students continuing their college studies. Analysis of the data using the Percentage formula.Results of the research are the students' interest to continuing their higher education at SMK Negeri 1 Talang Ubi, which consisted of 30 students, most of them were in the High $(T)$ category with a total frequency of 15 students or could be a percentage of a 50\% score. This was followed by the very high category (ST) with a total frequency of 10 students which could be compared with a value of $33.3 \%$. and then the student interest is in the medium category $(S)$ with a total frequency of 5 students which can be represented by a value of $16.7 \%$ and no student is in the low and very low category. Based on the data above, the average student interest in continuing their college studies is in the high category.In this case the guidance and counseling teacher plays an important role in maintaining student interest by providing direction to students to take part in socialization about college scholarships and attend college seminars so that they are always motivated to maintain interest in continuing college studies.

\section{Keywords: Interest, College.Service Guidance and Counseling}

\section{PENDAHULUAN}

Seiring dengan perkembangan zaman, perkembangan ilmu pengetahuan teknologi (IPTEK) sangat cepat berkembang, khususnya di Indonesia. Maka dari itu perlu untuk dipersiapkan sebaik mungkin dan ditanggapi dengan serius agar perkembangannya sesuai dengan kebutuhan pembangunan dalam mengahadapi laju perkembangan ilmu pengetahuan tersebut tentunya masyarakat Indonesia khususnya, harus mampu memanfaatkansebaik mungkin dengan kemampuan yang cukup dan tingkat adaptasi yang baik.Selain itu pendidikan merupakan salah satu mata rantai untuk memotong rantai kemiskinan dan kebodohan, pendidikan yang berkualitas bisa dicapai dengan jenjang pendidikan mulai dari Sekolah Dasar (SD), Sekolah Menengah Pertama (SMP), Sekolah Menengah Kejuruan (SMK) sampai Perguruan Tinggi.

Setiap siswa yang akan menyelesaikan studinya di SMK akan dihadapkan pada pilihan, yaitu dengan melanjutkan pendidikan keperguruan tinggi, mengikuti kursus, mencari pekerjaan atau menganggur. Bagi siswa yang akan menetapkan pilihan untuk melanjutkan ke perguruan tinggi, tentu akan dihadapkan lagi pada pilihan perguruan tinggi mana yang akan di masuki dan jurusan apa yang akan dipilih. Hal ini merupakan sebuah pilihan siswa yang memiliki minat yang tinggi untuk melanjutkan studi ke perguruan tinggi. Minat melanjutkan studi ke Perguruan Tinggi Negeri merupakan sebuah keinginan yang berasal dari diri 
siswa, yang disertai dengan tekat dan usaha. Menurut Crow dalam (Djaali 2007:121) mengemukakan bahwa, "Minat berhubungan dengan gaya gerak yang mendorong seseorang untuk menghadapi atau berurusan dengan orang, benda, kegiatan, pengalaman yang dirangsang oleh kegiatan itu sendiri.” Berdasarkan hal tersebut siswa yang memiliki minat akan mempunyai tekat dan usaha agar tujuannya tercapai. Hal tersebut tidak muncul begitu saja dari dalam dirinya, melainkan ada faktor-faktor yang menimbulkan minat.Diungkapkan oleh Bernard dalam (Ratna Setiawati, 2019:2) bahwa, "Minat tidak timbul secara tiba-tiba atau spontan, melainkan timbul dari partisipasi, pengalaman, kebiasaan pada waktu belajar dan bekerja." Minat dapat dipengaruhi oleh aktivitas belajar kemudian ada berbagai faktor belajar, baik faktor internal maupun eksternal. Faktor internal meliputi prestasi belajar, bakat (potensi diri), kebiasaan, kedisiplinan belajar, intelegensi, sikap, dan keadaan fisik. Sedangkan faktor eksternal meliputi lingkungan masyarakat, lingkungan sosial budaya, lingkungan sekolah, keadaan sosial ekonomi keluarga dan lain sebagainya.

\section{LANDASAN TEORI}

Minat lulusan SMK melanjutkan pendidikan ke perguruan tinggi tentu cukup beragam. Ada yang memiliki minat yang tinggi, minat yang sedang, dan rendah. Menurut Esti Setya Rini (2012:2) "Melanjutkan studi ke perguruan tinggi diawali dari adanya rasa ketertarikan dan kebutuhan untuk mengembangkan ilmu pengetahuan.” Rendahnya minat siswa untuk melanjutkan ke perguruan tinggi ini sangatlah disanyangkan, karena guru bimbingan dan konseling telah memberikan fasilitas berupa informasi yang dibutuhkan siswa tentang informasi perguruan tinggi, cara mendaftar, pembayaran serta menginformasikan tentang jalur masuk perguruan tinggi seperti jalur undangan dan bidikmisi. Namun masih banyak siswa SMK yang memilliki minat yang rendah.

Berdasarkan informasi yang diperoleh di SMK Negeri 1 Talang Ubi masih banyak permasalahan yang dihadapi oleh siswa yang berkenaan dengan minat untuk melanjutkan studi ke perguruan tinggi masih tergolong belum optimal, dikarenakan oleh minat beberapa siswa untuk belajar yang masih rendah hal ini terlihat dari rendahnya respon siswa terhadap kegiatan belajar mengajar didalam 
kelas. Sesuai dengan standar kompetensi siswa SMK yang telah disusun oleh Asosiasi Bimbingan dan Konseling Indonesia (ABKIN) tahun 2007.Agar dapat mengetahui persentase siswa yang memiliki minat rendah dalam melanjutkan studi perguruan tinggi dan implikasi pemberian bantuan yang dilakukan oleh guru bimbingan dan konseling kepada peserta didik agar memiliki minat melanjutkan studi perguruan tinggi sesuai kebutuhan dan keinginannya secara tepat. Hal ini sangat diperlukan untuk membangkitkan minat siswa yang nantinya ingin melanjutkan pendidikan diperguruan tinggi yang menjadi pilihannya.

Jadi, penelitian ini perlu dilakukan agar dapat mengetahui persentase siswa yang memiliki minat rendah dalam melanjutkan studi perguruan tinggi dan implikasi pemberian bantuan yang dilakukan oleh guru bimbingan dan konseling kepada peserta didik agar memiliki minat melanjutkan studi perguruan tinggi sesuai kebutuhan dan keinginannya secara tepat. Hal ini sangat diperlukan untuk membangkitkan minat siswa yang nantinya ingin melanjutkan pendidikan diperguruan tinggi yang menjadi pilihannya.

\section{METODE PENELITIAN}

Metode yang digunakan dalam pendekatan kuantitatif dengan metode deskriptif untuk mengetahui minat siswa dalam melanjutkan studi perguruan tinggi di SMK. Dengan metode deskriptif. Metode deskriptif adalah statistik yang digunakan untuk menganalisis data dengan cara mendeskripsikan atau mengambarkan data yang telah terkumpul sebagaimana adanya tanpa bermaksud membuat kesimpulan ( Sugiyono 2013:147).

Populasi yang di gunakan di dalam penelitian ini adalah kelas X TKRO hasil wawancara dengan guru bimbingan dan konseling bahwa siswa pada jurusan ini yang mayoritasnya anak laki-laki lebih banyak memilih langsung bekerja dari pada melanjutkan studi perguruan tinggi. Oleh karena itu populasi dan sampel yang saya ambil adalah jurusan Teknik Kendaraan Ringan Otomotif pada kelas X. Menurut Arikuto ( 2013 ; 173) Populasi merupakan keseluruhan subjek peneliti. Apabila seseorang ingin meneliti semua elemen yang ada di dalam wilayah penelitian maka penelitian nya merupakan penelitian populasi. 
Teknik pengambilan sampel yang digunakan dalam penelitian ini adalah purposive sampling, dilakukan karena sesuai dengan kriteria tertentu, yaitu siswa yang memiliki perasaan senang, ketertarikan, dan perhatian. Maka penelitian ini mengambil satu kelas yang berjumlah 30 siswa. Data penelitian diperoleh menggunakan observasi, wawancara. Menurut Sugiyono (2015:62) "Sampel penelitian adalah bagian dari jumlah dan karakteristik yang di miliki oleh populasi seperti karakteristik tertentu seperti adanya perasaan senang, ketertarikan, dan perhatian".

\section{METODEPENELITIAN}

Tabel 1. Deskripsi Rata-rata (Mean) dan Persentase (\%) Minat Siswa Melanjutkan Studi Perguruan Tinggi Berdasarkan Aspeknya

\begin{tabular}{|c|c|c|c|c|c|c|c|c|c|}
\hline \multirow[b]{2}{*}{ No } & \multirow[b]{2}{*}{ Aspek } & \multicolumn{7}{|c|}{ Skor } & \multirow[b]{2}{*}{ Ket } \\
\hline & & Ideal & Tertinggi & Terendah & Total & $\begin{array}{l}\text { Rata- } \\
\text { Rata }\end{array}$ & Sd & $\%$ & \\
\hline 1 & $\begin{array}{l}\text { PerasaanSenang } \\
\text { (4) }\end{array}$ & 20 & 20 & 12 & 473 & 15,76 & 2,72 & 78,8 & $\mathrm{~T}$ \\
\hline 2 & Ketertarikan (7) & 35 & 35 & 20 & 805 & 26,83 & 4,10 & 76,6 & $\mathrm{~T}$ \\
\hline 3 & Perhatian (6) & 30 & 30 & 14 & 646 & 21,53 & 3,95 & 71,7 & $\mathrm{~T}$ \\
\hline 4 & Aktivitas (5) & 25 & 25 & 11 & 579 & 19,3 & 20,01 & 77,2 & $\mathrm{~T}$ \\
\hline \multicolumn{2}{|c|}{ Keseluruhan } & 110 & 110 & 57 & 2503 & 83,42 & 30,78 & 75,83 & $\mathbf{T}$ \\
\hline
\end{tabular}

Catatan:

$$
\begin{array}{ll}
\text { Ket } & =\text { Keterangan } \\
\mathrm{T} & =\text { Tinggi } \\
\mathrm{Sd} & =\text { Standar deviasi }
\end{array}
$$

Berdasarkan tabel terlihat bahwa minat siswa pada aspek indikator berada pada kategori tinggi (T) dengan keseluruhan skor tertinggi yang dicapai sebesar 110 dan skor ideal adalah 110. Skor terendah keseluruhan adalah 57, skor total mencapai 2503, rata-rata skor adalah 83,42, skor total standar deviasi adalah 30,78 dengan tingkat capaian keseluruhan responden adalah 75,83\% sehingga dapat diinterpretasikan dalam kategori tinggi (T).

Selanjutnya dari hasil analisis data tampak bahwa skor tertinggi rata-rata minat siswa dalam melanjutkan studi perguruan tinggi pada aspek ketertarikan dengan rata-rata skor 26,83 atau dapat dipersentasekan dengan nilai $76,6 \%$, kemudian skor rata-rata terendah 15,76 terdapat pada aspek perasaan senang dengan nilai 
persentase $78,8 \%$ dan nilai tersebut sudah dapat diinterprestasikan dalam kriteria kategori tinggi.

Berdasarkan data di atas dapat dijelaskan bahwa minat siswa dalam melanjutkan studi perguruan tinggi SMK Negeri 1 Talang Ubi yang terdiri dari 30 siswa sebagian besar minat siswa berada pada kategori tinggi (T) dengan jumlah frekuensi 15 siswa atau dapat dipersentasekan dengan nilai 50\%. Kemudian disusul pada kategori sangat tinggi (ST) dengan jumlah frekuensi 10 siswa yang dapat dipersentasekan dengan nilai 33,3\%. kemudian minat siswa berada pada kategori sedang (S) dengan jumlah frekuensi 5 siswa yang dapat dipersentasekan $16,7 \%$ dan tidak ada siswa yang berada pada kategori rendah dan sangat rendah. Berdasarkan data diatas maka minat siswa dalam melanjutkan studi perguruan tinggi berada pada kategori tinggi.Minat siswa dalam melanjutkan studi perguruan tinggi juga dipersentasikan berdasarkan 4 aspek yang di lakukan dalam penelitian.

\section{PEMBAHASAN}

Hasil penelitian menunjukan aspek yang paling dominan adalah aspek ketertarikan pada minat siswa dalam melanjutkan studi perguruan tinggi yaitu rata-rata sebesar 26,83 dan persentase sebesar 76,6\%. Aspek ketertarikan ini sangat berpengaruh dalam melanjutkan studi perguruan tinggi, karena dengan adanya ketertarikan siswa akan selalu mencari tahu semua informasi yang terkait dengan perguruan tinggi yang mereka minati melalui berbagai macam media. Menurut Jandiko Saputra (2017:9)

Hasil penelitian menunjukan aspek perasaan senang dalam minat siswa melanjutkan studi perguruan tinggi yaitu rata-rata sebesar 15,76 dan persentase sebesar 78,8\%. Aspek ini merupakan aspek dengan rata-rata terendah dan aspek perasaan senang ini sangat berpengaruh positif terhadap minat siswa dalam melanjutkan studi ke perguruan tinggi, karena siswa beranggapan bahwa dirinya sudah bisa menentukan pilihan untuk masa depannya sehingga siswa tersebut akan terus mempelajari ilmu yang disenangi sesuai kemampuan yang dimilikinya serta mampu menyampaikan pendapat tanpa adanya paksaan dari orang-orang sekitar. Menurut Jandiko Saputra (2017:9) Seorang siswa yang memiliki perasaan 
senang atau suka terhadap suatu mata pelajaran, maka siswa tersebut akan terus mempelajari ilmu yang disenanginya. Tidak)

Hasil penelitian menunjukan perhatian dalam melanjutkan minat studi perguruan tinggi yaitu rata-rata sebesar 21,53 dan persentase sebesar 71,7\%. Aspek perhatian merupakan suatu reaksi siswa yang tertuju pada suatu objek secara sadar. Dengan adanya aspek perhatian ini siswa secara sadar memperhatikan semua hal yang berkaitan dengan perguruan tinggi seperti mencari tahu kelemahan dan kelebihan yang dimiliki perguruan tinggi yang mereka minati. Menurut Jandiko Saputra (2017:9)

Selanjutnya hasil penelitian menunjukan aktivitas minat siswa dalam melanjutkan studi perguruan tinggi yaitu rata-rata sebesar 19,3 dan persentase sebesar 77,2\%. Aktivitas merupakan suatu tindakan spontan yang dilakukan oleh siswa dalam mencari tahu mengenai tata cara masuk dan berusaha mencari referensi mengenai perguruan tinggi yang mereka minati. Menurut Prayitno dkk (2009:114), "Tujuan bimbingan dan konseling adalah untuk membantu perkembangan diri individu secara optimal sesuai dengan tahap perkembangan yang dimilikinya (seperti kemampuan dasar dan bakatnya). Minat siswa melanjutkan studi perguruan tinggi ini berada pada kategori tinggi karena sudah ada layanan informasi mengenai minat melanjutkan studi perguruan tinggi. Walaupun minat siswa dalam melanjutkan studi perguruan tinggi ini berada pada kategori tinggi tetapi tetap diberikan arahan oleh guru bimbingan dan konseling karena dari data alumni yang ada bahwa minat melanjutkan studi perguruan tinggi pada siswa TKRO sangat rendah yang disebabkan oleh beberapa faktor, salah satunya yaitu faktor ekonomi yang dimana menjadi salah satu faktor yang paling tinggi siswa tidak bisa melanjutkan studi ke perguruan tinggi.

\section{KESIMPULAN}

Berdasarkan hasil penelitian yang penulis lakukan mengenaiminat Siswa dalam Melanjutkan Studi ke Perguruan Tinggi Siswa Kelas X TKRO SMK NEGERI 1 Talang Ubi.Maka penulis akan mengemukakan kesimpulan sebagai berikut: 
Berdasarkan hasil analisis data deskripsi, pengujian hasil penelitian, dan pembahasan, dapat diambil kesimpulan bahwa gambaran minat siswa dalam melanjutkan studi perguruan tinggi di SMK Negeri 1 Talang Ubi yang terdiri dari 30 siswasebagian besar minat mereka berada pada kategori tinggi (T) dengan jumlah frekuensi 15 siswa atau dapat dipersentasekan dengan nilai 50\%, kategori sangat tinggi (ST) dengan jumlah frekuensi 10 siswa atau dapat dipersentasekan 33,3\%, kategori sedang (S) jumlah frekuensinya 5 siswa atau dipersentasekan menjadi $16,7 \%$, dan tidak ada siswa yang berada pada kategori rendah dan sangat rendah. Berdasarkan data diatas maka minat siswa dalam melanjutkan studi perguruan tinggi di SMK Negeri 1 Talang Ubi berada pada kategori tinggi.

Hal yang dilakukam guru bimbingan dan konseling tetap memberikan arahan agar minat siswa tidak terjadi penurunan seperti melakukan sosialisasi mengenai beasiswa dan mengikuti seminar perguruan tinggi agar mereka selalu termotivasi dalam mempertahankan minat agar mampu menempatkan jurusan sesuai kemampuan yang dimilikinya

Berdasarkan hasil penelitian yang telah diperoleh, maka peneliti memberikan saran kepada beberapa pihak terkait yang dapat dijadikan bahan pertimbangan, yaitu sebagai berikut:

1. Kepada siswa kelas $X$ yang memiliki minat melanjutkan studi sangat tinggi diharapkan untuk dapat mempertahankan dan yang memiliki minat cukup diharapkan untuk dapat meningkatkannya, karena dengan memiliki minat yang tinggi kita mampu menetapkan sesuai kemampuan yang kita miliki.

2. Guru bimbingan dan konseling dapat memberikan layanan informasi tentang kelebihan dan kekurangan melanjutkan perguruan tinggi serta bagaimana caranya untuk melanjutkan studi perguruan tinggi.

3. Kepada seluruh jajaran guru SMK Negeri 1 Talang Ubi agar selalu memberikan dorongan, informasi tentang perguruan tinggi, serta memberikan motivasi terhadap siswa mengenai keberhasilan yang akan dicapai setelah melanjutkan studi perguruan tinggi.

4. Kepada Orang tua baiknya selalu memberikan dukungan pada anaknya yang berminat melanjutkan studi perguruan tinggi dengan memberikan dorongan dan semangat guna mencapai masa depan yang lebih baik lagi. 
5. Kepadacalonpenelitilain agar dapat melakukan penelitian kualitatif terhadap guru bimbingan dan konseling bagaimana peran guru bimbingan dan konseling mempertahankan minat siswa dalam melanjutkan studi perguruan tinggi.

\section{DAFTAR PUSTAKA}

ABKIN. 2007. Rambu-rambu penyelenggaran bimbingan dan konseling dalam jalur pendidikan formal. Bandung: ABKIN

Arikunto Suharsimi. 1993. Prosedur Penelitian Suatu Pendekatan Praktik. Jakarta:Rineka Cipta, Edisi Revisi 11 cet.ke IX.

Djaali. 2007. Psikologi Pendidikan. Jakarta: PT. Bumi Aksara

Esti, Setya Rini. 2012. Hubungan tingkat pendidikan orang tua dan prestasi belajar siswa dengan minat melanjutkan studi ke perguruan tinggi pada siswa kelas XI SMA Negeri 1 Kalasan tahun ajaran 2011/2012. Skripsi. $\begin{array}{lllll}\text { Diakses pada tanggal } 25 & \text { desember } & 2020\end{array}$ http://journal.uny.ac.id/index.php/jkpai/article/view/878

Jandiko Saputra. 2017. Upaya Guru Bimbingan Konseling Dalam Meningkatkan Minat Melanjutkan Ke Perguruan Tinggi Di Sma Negeri 1 Membalong Kelas Xii Tahun Ajaran 2016/2017.diakses pada 25 Januari 2020 jam 23:33.

Prayitno Dkk. 2017. Layanan Bimbingan Kelompok \& Konseling Kelompok.Bogor : Ghalia Indonesia.

Ratna setiawati. 2019. Pengaruh potensi diri, disiplin belajar, dan sosial, ekonomi orang tua terhadap minat melanjutkan studi keperguruan tinggi negeri melalui prestasi belajar siswa kelas XII SMA Negeri Seputih Mataram tahun 2018/2019. Skripsi. diakses pada 26 Febuari 2019

Sugiyono. 2013. Metode penelitian pendidikan : pendekatan kuantitatif, kualitatif, dan R\&D. Bandung : Alfabeta.

Sugiyono. 2015. Metode penelitian pendidikan : pendekatan kuantitatif, kualitatif, dan R\&D. Bandung : Alfabeta.

Sugiyono. 2018. Metode penelitian pendidikan : pendekatan kuantitatif, kualitatif, dan R\&D. Bandung : Alfabeta. 